\title{
Effects of Personal Variables of Call Centre Employees on their
}

\section{Psychological well being}

\author{
Nitin R. Korat*, Gandharva R. Joshi**
}

\begin{abstract}
The study was designed to investigate the impact of certain personal variables on psychological well being of call centre employees. The sample consisted of 240 call centre employees (120 Male/120 Female) selected randomly from Vodafone Call Centre of Ahmedabad city. Psychological well being scale of Dr. Bhogle and Prakash was used. Results revealed that there exists a significant difference between psychological well being and variables such as Sex, Age, Type of Family, work Shifts and working time of Call center employees. No significant deference observed between Psychological well being of married and unmarried employees. And also no significant difference was found between Psychological well being and Education of Call centre employees.
\end{abstract}

KEYWORDS: Psychological well being, call centre employees of mobile company.

The call center industry has exploded worldwide over the past two decades, as advances in information and communication technologies have reduced the costs of providing service and sales from remote locations. The numbers of people working in call centers. The call-centre environment can be challenging for customer service representatives, employee well being should be an important consideration for employers. At the same time, there has been a growing awareness that the work can be stressful and repetitive with little individual discretion. Most people have had the experience of calling a call center, only to become frustrated or angry when the call center agent was unable to solve their problem. If employees fail to meet targets, they are often threatened with dismissal or a pay cut. These conditions have contributed to high levels of employee stress, anxiety, and burnout in call centers. The work of a call center agent is seen as one of the ten most stressful jobs in the global economy (Holdsworth and Cartwright 2003). This paper will focus on psychological well being of employees.

*Research Scholar, **Professor, Department of Psychology, Saurashtra University Rajkot360005 . 
During the last two decades, mental health has to be define in terms of psychological well being low psychological well being is illustrated in anxiety, depression, low morale, lack of self confidence, low sense of personal autonomy, inability to cope with the problems of living and dissatisfaction with one self and the physical environment. Mental health is fundamental component of health through which one realizes one's own cognitive affective and relational abilities. It can be define as the ability to adjustment to the environment on the plan of reality. "Well being is a positive and sustainable condition that allows individuals, groups or nations to thrive and flourish. (Huppert, Baylis \& Keverne., 2005)"

Numerous studies have investigated effects of working conditions on strain (Kahn \& Byosiere, 1992; Sonnentag \& Frese, 2003). For instance, resources at work such as job control are in general positively related to wellbeing, health and job-related attitudes (Semmer, 1998; Terry \& Jimmieson, 1999). Moreover, job demands like job complexity and variety have the same effects on well-being and job-related attitudes as resources at work as long as they do not overtax a person's capabilities and as long as they allow utilizing one's skills, knowledge, and abilities and therefore, promote learning. Positive relationships of job complexity and variety with well-being and job-related attitudes have been reported both in the literature on stress at work in general (Kahn \& Byosiere, 1992; Sonnentag \& Frese, 2003; Warr, 1999) and specifically for call agents, while control, complexity, and variety are associated with well-being, good health, and positive job-related attitudes, the opposite applies to stressors at work.

Holman (2002) described findings for four measures of well-being, namely, anxiety, depression, intrinsic and extrinsic job satisfaction. Deery, S., Iverson, R., \& Walsh, J. (2002) conducted research in five call centers of a large Australian telecommunications organization. The Deery (2002) paper is concerned with the identification of the factors that are associated with emotional exhaustion and the frequency of absence amongst call centre employees.

\section{Objective}

The main aim of this study was to investigate the impact of the personal variables of call center employees on their Psychological well being. 
The International Journal of Indian Psychology: Volume: 01 | Issue: 04 No. 2 | ISSN 2348-5396

\section{Hypotheses}

1. There is no significant difference between Psychological well being of male and female call centre employees.

2. There is no significant difference between Psychological well being and education of call centre employees.

3. There is no significant difference between Psychological well being and age of call centre employees.

4. There is no significant difference between Psychological well being and work shifts of call centre employees.

5. There is no significant difference between Psychological well being and types of family of call centre employees.

6. There is no significant difference between Psychological well being and marital status of call centre employees.

7. There is no significant difference between Psychological well being and working time of call centre employees.

\section{METHOD}

\section{Samples}

The sample size was 120 Call centre employees, comprising of 75 Male and 75 Female employees from Vodafone call centers of Ahmedabad. All were aged between 19 to 36 years. The collected information can be managed carefully and more accurately.

\section{Measure}

Psychological well-being Questionnaire: it was developed by Bhogle and Prakash (1995), was used to measure Psychological well-being. The questionnaire contains 28 items with true and false response alternative. It covers 13 dimensions of psychological well-being. The maximum possible score is twenty eight and minimum is zero. High score indicates high level of psychological well-being. The test - retest reliability coefficient is 0.72 and internal consistency coefficient is 0.84 . The author has reported satisfactory validity of the questionnaire. 
The International Journal of Indian Psychology: Volume: 01 | Issue: 04 No. 2 | ISSN 2348-5396

\section{RESULT AND DISCUSSION}

Table: 1 Analysis of variance based on psychological well being of call centre employees with respect to Sex, Education and Age

\begin{tabular}{|l|l|l|l|l|}
\hline Source of Variation & Sum of Square & df & $\begin{array}{l}\text { Mean Sum of } \\
\text { Square }\end{array}$ & F \\
\hline A (Sex) & 147.27 & 1 & 147.27 & $12.34^{*}$ \\
\hline B (Education) & 29.39 & 1 & 29.39 & $2.46 \mathrm{NS}$ \\
\hline C(Age) & 336.07 & 1 & 336.07 & $28.17^{*}$ \\
\hline AxB & 178.69 & 1 & 178.69 & $14.98^{*}$ \\
\hline AxC & 688.69 & 1 & 688.69 & $57.73^{*}$ \\
\hline BxC & 369.22 & 1 & 369.22 & $30.95^{*}$ \\
\hline AxBxC & 740.89 & 1 & 740.89 & $62.10^{*}$ \\
\hline Between & 2490.22 & & & \\
\hline Within error & & 232 & & \\
\hline Total & & 239 & & \\
\hline
\end{tabular}

NS $=$ Not Significant, $*$ P $<0.01$

According to table No. 1 it is observed that ' $F$ ' value of psychological well-being of male and female call centre employee is 12.34 which exhibit significant difference even at a level of 0.01 . From these results it can be concluded that male and female call centre employee differ as far as their psychological well-being is concerned. No significant difference between the male and female participants in this area of self-acceptance suggests that both genders have similar experience and difficulty in this area of psychological well-being which is contradict to the results obtained by Roothman and colleagues (2003). Therefore refusing null hypothesis if can be said that sex affects ones psychological wellbeing. It is observed from table No.1 that ' $F$ ' value of psychological well-being amongst level of education of employee is 2.46 which do not exhibit significant difference even at a level of 0.05 . This result supports the results obtained by Christine A. Sprigg, Phoebe R. Smith, Paul. R. Jackson(2003). 'F' value of psychological wellbeing amongst call centre employees according to their age is 28.17 which is significant at a level of 0.01 . With growing age the status and work load of the existing role also decrease in addition a decrease is found in physical and emotional works that leads to limit one's movements around and communication with others. This in turn leads to lack of life satisfaction and 
The International Journal of Indian Psychology: Volume: 01 | Issue: 04 No. 2 | ISSN 2348-5396

emotions like anger, depression, worries etc are found to be increasing Dhillon (1992). This physical and mental well-being decreases with age. therefore, hypothesis three is rejected.

Table: 2 t-test comparison based on psychological well being of call centre employees with respect to work shifts, types of family, marital status and working time

\begin{tabular}{|l|l|l|l|l|l|}
\hline Variable & $\mathrm{N}$ & SD & Mean & SED & $\mathrm{t}$ \\
\hline $\begin{array}{l}\text { Work shifts } \\
\text { Day shift }\end{array}$ & 60 & 3.42 & 20.62 & & \\
\hline $\begin{array}{l}\text { Night shift } \\
\text { Types of family }\end{array}$ & 60 & 4.07 & 19.12 & 0.69 & $2.17^{*}$ \\
\hline Joint Family & 90 & 3.9 & 21.14 & & \\
\hline Nuclear Family & 150 & 3.84 & 20.06 & 0.51 & $2.11^{*}$ \\
\hline Marital status & & & & & \\
\hline Married & 90 & 3.57 & 19.74 & & $0.55 \mathrm{NS}$ \\
\hline Unmarried & 150 & 3.90 & 19.47 & 0.49 & \\
\hline Working time & $18 \mathrm{TM}$ & & & & $3.00^{* *}$ \\
\hline Full time & 180 & 3.77 & 19.33 & & \\
\hline Part time & 60 & 3.85 & 21.07 & 0.58 & \\
\hline
\end{tabular}

NS $=$ Not Significant, $* \mathrm{P}<0.01, * * \mathrm{P}<0.05$

In order to know the difference between groups ' $t$ ' is calculated after ANOVA in present study, ' $t$ ' values on shown in table No. 2. From these findings it can be said that ' $t$ ' value of means obtained for the psychological well-being of day shift employees and night shift employee is 2.17 which is positive at a level of 0.01 . The ' $t$ ' value of scores of psychological well-being of joint and nuclear family employee is 2.11 which is also showing positive at a level of 0.01 . The ' $t$ ' value of scores of psychological well being of married and unmarried employee is 0.55 which does not show significant. The ' $t$ ' value of scores of psychological well-being of full time and part time working employee is 3.00. This value is significant at a level of 0.05. Following finding support this result no statistically significant differences in relation to well-being between call handlers who work part-time and those that do not work part time Christine A. Sprigg, Phoebe R. Smith, Paul. R. Jackson (2003). 
The International Journal of Indian Psychology: Volume: 01 | Issue: 04 No. 2 | ISSN 2348-5396

\section{CONCLUSION}

The psychological well-being amongst male and female call centre employees is significant as well as age wise, work shifts wise, types of family wise and working shifts wise psychological well being of call centre employees differ positively whereas, education and marital status do not affect psychological well being of call centre employees.

\section{REFERENCE}

1. Christine A. Sprigg, Phoebe R. Smith, Paul. R. Jackson (2003). Psychosocial risk factors in call centres: An evaluation of work desighn and well being. The text of the Health and Safety Executive 31-32 (ISBN 071762774 8).

2. Deery, S., Iverson, R., \& Walsh, J. (2002). Work relationships in telephone call centres: understanding emotional exhaustion and employee withdrawal.Journal of Management Studies, 39(4), 471-496.

3. Dhillon (1992). Personality, anxiety and self-concept: A study across age variation and social class. In P.K. Dhillon (Eds.) Psychosocial aspects of aging in India (PP.119- 136). New Delhi: Concept Publishing.

4. Holdsworth, L., \& Cartwright, S. (2003). Empowerment, stress and satisfaction: an exploratory study of a call centre. Leadership \& Organization Development Journal, 24(3), 131-140.

5. Holman, D. (2002). Employee wellbeing in call centres. Human Resource Management Journal, 12(4), 35-50.

6. Huppert, Baylis, keverne., (2005). The science of Well being . Oxford: Oxford university press; 2005.

7. Kahn, R. L., \& Byosiere, P. (1992). Stress in organizations. In M. D. Dunnette \& L. M. Hough (Eds.), Handbook of industrial and organizational psychology (2nd ed., pp. 571 650). Palo Alto, CA: Consulting Psychologists Press.

8. Roothman, B., Kirsten, D., Wissing, M. (2003). Gender differences in aspects of psychological well-being. South African Journal of Psychology, 33(4), 212-218.

9. Sonnentag, S., \& Frese, M. (2003). Stress in organizations. In W. C. Borman, D. R. Ilgen, \& J. R. Klimoski (Eds.), Comprehensive handbook of psychology. Vol. 12: Industrial and organizational psychology. New York: Wiley.

10. Terry, D. J., \& Jimmieson, N. L. (1999). Work control and employee well-being: A decade review. In C. L. Cooper \& I. T. Robertson (Eds.), International review of industrial and organizational psychology (Vol. 14, pp. 95 - 148). Chichester, UK: Wiley.

11. Warr, P. (1999). Well-being and the workplace. In D. Kahneman, E. Diener, \& N. Schwarz (Eds.), Well-being: The foundations of hedonic psychology (pp. 393 - 412). New York: Russell Sage Foundation. 